\title{
ADVERSE EVENTS RELATED TO THE USE OF PERIPHERAL INTRAVENOUS CATHETERS IN CHILDREN ACCORDING TO DRESSING REGIMENS
}

\author{
Ariane Ferreira Machado ${ }^{1}$ \\ Mavilde da Luz Gonçalves Pedreira² \\ Massae Noda Chaud
}

Machado AF, Pedreira MLG, Chaud MN. Adverse events related to the use of peripheral intravenous catheters in children according to dressing regimens. Rev Latino-am Enfermagem 2008 maio-junho; 16(3):362-7.

A randomized, controlled study was implemented to verify reasons to release and adverse events related to the use of peripheral intravenous catheters in children, according to the dressing regimens The sample was set at 150 peripheral intravenous catheters, randomly assigned to three groups: sterile gauze dressings, sterilized transparent film dressings, and non sterile hypoallergenic adhesive tape. The data was collected after consent had been obtained by the Ethics Committee, including children who had been submitted to catheterization with Teflon ${ }^{\circledR}$ over the needle catheters. Statistical tests were performed by applying the Pearson Chi-square test, significance level set at $p \leq 0.05$. The results showed that dressing regimens influenced the reasons for catheter removal and occurrence of adverse events, mainly due to infiltration (55.3\%). The Sterile gauze showed the best performance $(p=0.002)$ in comparison with the other studied groups, once $40.0 \%$ of the catheters were removed by release from treatment.

DESCRIPTORS: pediatric nursing; catheterization peripheral; infusions intravenous/adverse effects

\section{EVENTOS ADVERSOS RELACIONADOS AL USO DE CATÉTERES INTRAVENOSOS PERIFÉRICOS EN NIÑOS SEGÚN LOS TIPOS DE CURATIVOS}

Se trata de un estudio aleatorio y controlado que tuvo como objetivo identificar los motivos de retirada y los eventos adversos relacionados al uso de catéteres intravenosos periféricos en niños según el tipo de curativo. La muestra fue constituida por 150 catéteres distribuidos en tres grupos, compuestos por: curativo con gasa estéril, película transparente y fijación con cinta adhesiva hipoalergénica no estéril. La recolección de datos ocurrió después de la aprobación del merito ético, incluyéndose en el estudio niños sometidos a la punción intravenosa periférica, con catéteres de Teflón ${ }^{\circledR}$ fuera de la aguja. Para analizar la correlación entre las variables fue utilizada la prueba de Chi-cuadrado de Pearson, siendo considerados significativos los valores de pd"0,05. Los resultados evidenciaron que los curativos influenciaron los motivos de retirada del catéter y la ocurrencia de eventos adversos, destacándose la infiltración (55,3\%). El curativo con gasa, en comparación con los otros grupos estudiados, presentó una menor proporción de eventos adversos $(p=0,002)$, siendo que $40,0 \%$ de los catéteres fueron retirados por el alta del tratamiento.

DESCRIPTORES: enfermería pediátrica; cateterismo periférico; infusiones intravenosas/efectos adversos

\section{EVENTOS ADVERSOS RELACIONADOS AO USO DE CATETERES INTRAVENOSOS PERIFÉRICOS EM CRIANÇAS DE ACORDO COM TIPOS DE CURATIVOS}

Estudo randomizado e controlado que objetivou identificar motivos de retirada e eventos adversos relacionados ao uso de cateteres intravenosos periféricos em crianças segundo tipo de curativo. A amostra foi ajustada em 150 cateteres distribuídos em três grupos, compostos por curativo com gaze estéril ou película transparente e fixação com fita adesiva hipoalergênica não estéril. A coleta de dados ocorreu após aprovação do mérito ético, incluindo-se no estudo crianças submetidas à punção intravenosa periférica, com cateteres fora da agulha de Teflon ${ }^{\circledR}$. Para análise de correlação entre variáveis foi utilizado teste do Qui-quadrado de Pearson, sendo considerados significantes valores de $p \leq 0,05$. Os resultados evidenciaram que os curativos influenciaram os motivos de retirada do cateter e a ocorrência de eventos adversos, destacando-se a infiltração (55,3\%). O curativo com gaze em comparação com os outros grupos estudados apresentou menor proporção de eventos adversos ( $p=0,002)$, sendo $40,0 \%$ dos cateteres retirados por alta do tratamento.

DESCRITORES: enfermagem pediátrica; cateterismo periférico; infusões intravenosas/efeitos adversos

${ }^{1}$ RN, MNS, Nurse Coordinator, Pediatric Surgery Ward, São Paulo Hospital, Federal University of São Paulo, Brazil, e-mail: ariane.ferreira3@terra.com.br; ${ }^{2}$ RN, PhD, Nursing Professor at Federal University of São Paulo, Brazil, e-mail: mavilde@denf.epm.br; massae@denf.epm.br 


\section{INTRODUCTION}

Intravenous therapy although one of the most commonly performed procedures in hospitalized patients, may make them susceptible to infectious and non-infectious adverse events ${ }^{(1)}$. Approximately $1 \%$ to $10 \%$ of such patients develop local or systemic catheter-related infections caused by alteration or disruption of skin integrity which can be an open pathway for colonization by microorganisms ${ }^{(2-3)}$.

Complications such as phlebitis, infiltration and tissue extravasation are described as peripheral venous catheter-related adverse events ${ }^{(4-5)}$. Complications may be ascribed to a number of factors such as the selected type of catheter, insertion site preparation, type of infusion, insertion technique, length of catheter placement, type of dressing and the chosen insertion site ${ }^{(4,6-7)}$.

Teflon ${ }^{\circledR}$ and Polyurethane catheters show lower infection complication rates compared to Polyvinylchloride and Polyethylene varieties. According to the Center for Disease Control and Prevention guidelines, adult patient's catheters should be replaced within a 72-96 hours period in order to reduce complications such as infections or phlebitis ${ }^{(6)}$. In pediatric patients however, the relationship between long catheter placement and the occurrence of phlebitis was not evidenced and the catheters can be maintained until the end of therapy, or until clinical signs of complications are observed.

The use of an appropriate type of dressings is intended to keep the insertion site clean and dry while also preventing external contamination and trauma ${ }^{(4,8)}$. There are reports that dressing regimens and methods of securing catheters may contribute to the occurrence of infection complications such as phlebitis, and mechanical complications including infiltration, extravasation, and catheter displacement ${ }^{(2)}$.

The literature indicates that sterile gauze, sterilized transparent film and hypoallergenic adhesive tape, are the most suitable types of material to be used for dressings and peripheral venous catheter fixation ${ }^{(2,9)}$.

Both sterile gauze and adhesive strips were used as dressings in peripheral venous catheter insertions throughout the first 50 years of intravenous therapy practice in the last century ${ }^{(8)}$. The use of transparent sterilized films was adopted during the 1970 's as a consequence of nurses' requests regarding the need to remove gauze dressings to inspect the catheter insertion site $^{(2)}$.
Some healthcare facilities still make use of non-sterile adhesive tape dressings, practice widely observed in developing countries. However, contamination can easily occur as soon as the originally sealed material packaging is opened and applied to the insertion site ${ }^{(1)}$.

Reporting the occurrence of complications according to different types of dressings, a systematic review and meta-analysis, demonstrated the absence of any relationship between the type of dressing used in peripheral venous catheter insertion sites and the occurrence of phlebitis, infiltration, or skin dwelling bacteria in adult patients ${ }^{(1)}$.

A study related to the length of catheter placement according to the dressing regimes performed by this researchers and published in the Latin American Journal of Nursing in 2005 demonstrated that the type of dressing exerted a significant influence $(p=0.022)$ on the average dwell time of the studied catheters, concluding that the dressing with sterile gauze maintained the catheter placed for a longer time ${ }^{(10)}$.

Controlled studies investigating dressings for the prevention of peripheral venous catheter complications mainly have reported results obtained in temperate climate countries. The present investigation was focused on verifying whether different types of dressings - adhesive tape, sterile gauze, and sterilized transparent film - used in a country with a warm and humid tropical climate and different individual cutaneous flora, would influence the reasons for removal and the occurrence adverse events related to the use of peripheral intravenous catheters inserted in children.

\section{METHODS}

A randomized, controlled study was developed from February to May 2002, implemented in children aged between 0 and 12 years old who had been submitted to catheterization with Teflon ${ }^{\circledR}$ over the needle catheters. Subjects were under hospital care in a nine-bed pediatric surgical unit of a university hospital located in the city of São Paulo, Brazil. Parents or legally authorized persons responsible for the children's welfare were then asked to sign an informed consent before trial onset, after being made aware of the research procedures. 
The hypothesis $(\mathrm{H})$ presented by the study was that the "reason for peripheral venous catheter removal and occurrence of adverse events would be different in children submitted to intravenous therapy, according to three dressing regimens".

The sample was randomly assigned to three groups using a table of pseudo-random numerals. For the formation of the study groups, the total sample size was set at 150 peripheral venous catheters, after statistical assessment of the data obtained during a previous test. This sample size was designed to give a confidence level of $95 \%$. No previous studies carried out on the subject for the population of the study country were identified in the literature. This fact made comparison of the study's impact impossible, remaining one of its limitations.

The Control Group included 50 peripheral venous catheters secured by adhesive tape designated as conventional dressing - applied in 37 children. Experimental Group I included 50 peripheral venous catheters inserted in 40 children that used sterile gauze dressings, whilst Experimental Group II included 32 children that utilized inserted peripheral venous catheters and the sterilized transparent film dressings.

Material and dressing procedures included the conventional dressing used in the studied institution - applied in the control group, using hypoallergenic adhesive tape measuring $5 \mathrm{~cm}$ long by $2.5 \mathrm{~cm}$ wide. One of the strips was applied over the catheter insertion site while the other was used to secure the catheter lead. The sterile gauze dressings measuring $2 \mathrm{~cm} \times 2 \mathrm{~cm}$ were secured to the insertion site by means of a section of adhesive hypoallergenic tape measuring $5 \mathrm{~cm}$ by $2.5 \mathrm{~cm}$. The sterilized transparent film, a thin sterile semi permeable polyurethane layer dressing measuring $5 \mathrm{~cm} \times 4 \mathrm{~cm}$ was selected in view of its three to eight times greater permeability level, which in turn facilitates the child's skin perspiration.

Prior to the placing of the dressing in all three regimens, a hypoallergenic tape strip measuring 10 $\mathrm{cm}$ in length and $2 \mathrm{~cm}$ in width, was positioned with its adhesive side under the catheter while the two extremities of its lengths were crossed over to form a " $V$ " shape when pressed against the skin, distant from the catheter's insertion site.

Some variables were studied to allow the description of the patients and intravenous therapy implementation. These variables named as homogenization variables, included children-oriented characteristics such as age, nutritional status (determined by the Z-Score), skin color, gender, and medical diagnosis. Homogenization variables also included those on the professionals who carried out intravenous catheter insertion and dressing procedures, such as healthcare professionals' work category and length of nursing experience in the pediatrics.

In addition to variables concerning children and professionals, a number of intravenous therapy characteristics were also selected: catheter fixation site, limb immobilization, continuous or intermittent catheter maintenance, required use of heparin solution flush $(10 \mathrm{U} / \mathrm{ml})$, use of total parenteral nutrition, antibiotic therapy and the number of combined antibiotics administrated. Dependent variables comprised both the reason for catheter removal, and the peripheral venous catheter length of permanence.

Reasons for catheter removal were release from treatment and adverse events such as phlebitis, infiltration, blood flow block, kinking, accidental catheter removal ${ }^{(11-12)}$.

Phlebitis, meaning inflammation of a vein, was identified by a visible red, cord-like vein which generally feels hard, warm and tender and leads to a throbbing or burning sensation beneath the skin's surface, with or without purulent drainage from the catheter insertion site ${ }^{(11)}$. According to the Infusion Nurses Society, the Phlebitis Rating Scale determine the following grades: Grade 0: no clinical symptoms; Grade 1: presence of erythema at access site with or without pain; Grade 2: Pain at access site with erythema and/or edema; Grade 3: Pain at access site with erythema and/or edema, streak formation, palpable venous cord; Grade 4: presence of pain at access site, erythema and/or edema, streak formation, and palpable venous cord $>1$ inch in length, purulent drainage observed ${ }^{(11)}$.

Infiltration was also evaluated based on the presence of a cold skin region around the insertion site, dependent edema, and absent or slow continuous infusion rate. Grading infiltration scale, according to the Infusion Nurses Society guidelines showed Grade 0: no symptoms; Grade 1: skin blanched, edema $<1$ inch in any direction, cool to touch, with or without pain; Grade 2: Skin blanched, edema 1-6 inches in any direction, cool to touch, with or without pain; Grade 3: Skin blanched, translucent, gross edema > 6 inches in any direction, cool to touch, mild-moderate pain, possible numbness; Grade 4: skin blanched, translucent, tight, leaking, discolored, bruised, swollen, gross edema $>6$ inches in any direction, deep pitting tissue edema, circulatory impairment, moderatesevere pain, infiltration of any amount of blood product, irritant, or vesicant ${ }^{(11)}$. 
Prior to data collection, all the healthcare professionals involved received the Procedures Manual and underwent training on skin antisepsis (alcohol $70 \%)$, peripheral venous puncture insertion and removal procedures as well as dressing care instructions. Teaching material and technique training were made available.

Statistical test were performed by applying the Pearson Chi-square test. Rejection of the null hypotheses was established at $5 \%$.

\section{RESULTS}

The sample included 150 catheters inserted in 68 children distributed into three groups.

Results attained through the analysis of the children's homogenization variables show the inexistence of a statistically significant difference between the three studied groups. Subjects were predominantly of preschool age (median 5 years old) in the three studied groups $(p=0.523), 60.0 \%$ were males $(p=0.920)$, and $73(48.7 \%)$ children were mulattoes $(p=0.526)$. Additionally, no nutritional alteration was observed in 124 (82.7\%) children, whilst $103(68.7 \%)$ individuals were recovering from surgically treated gastrointestinal diseases. The distribution of these characteristics was similar in all three of the studied groups $(p=0.916$ and $p=0.886$ respectively).

Variables related to the healthcare professional work category were studied and the application of the Chi-square test demonstrated a statistically significant difference $(p=0.029)$ between the peripheral venous puncture performers across the three dressing groups. Comparisons showed Experimental Group II as having a larger proportion of registered nurses (38.0\%) whereas the Control Group presented the largest proportion of nursing technicians (56.0\%) and Experimental Group I comprised the largest proportion of Nursing Residence Program students (24.0\%). Peripheral venous puncture performers had a mean of eight years' experience in pediatric nursing, and the length of experience was similar across the three studied groups $(p=0.714)$

Catheter 24G caliber had been the most widely used $(72.0 \%)$ and the catheter caliber did not show a statistically significant difference among the studied groups $(p=0.743)$. Limb immobilization did not present statistically significant difference between the three groups $(p=0.224)$ where an immobilizing splint device was generally used for limb immobilization (90.7\%) in all studied groups.

Table 1 shows results related to reasons for catheter removal and the dressing regimens had a significant effect on some the dependent variables.

Table 1 - Reasons for peripheral venous catheter removal, concerning to three dressings regimens, São Paulo, 2002

\begin{tabular}{|c|c|c|c|c|c|}
\hline Variable & CG & EG I & EG ॥ & Total & $\begin{array}{c}\text { Statistical } \\
\text { test }\end{array}$ \\
\hline \multicolumn{6}{|c|}{ Release from treatment } \\
\hline Yes & $12(24.0 \%)$ & $20(40.0 \%)$ & $5(10.0 \%)$ & $37(24.7 \%)$ & \multirow{2}{*}{$p=0.002$} \\
\hline No & $38(76.0 \%)$ & $30(60.0 \%)$ & 45 (90.0\%) & $113(75.3 \%)$ & \\
\hline \multicolumn{6}{|c|}{ Adverse events } \\
\hline Yes & $38(76.0 \%)$ & $30(60.0 \%)$ & $45(90.0 \%)$ & $113(75.3 \%)$ & \multirow[t]{2}{*}{$p=0.015$} \\
\hline No & $12(24.0 \%)$ & $20(40.0 \%)$ & $5(10.0 \%)$ & $37(24.7 \%)$ & \\
\hline \multicolumn{6}{|l|}{ Phlebitis } \\
\hline Yes & $5(10.0 \%)$ & $1(2.0 \%)$ & $1(2.0 \%)$ & $7(4.7 \%)$ & \multirow{2}{*}{$p=0.091$} \\
\hline No & $45(90.0 \%)$ & 49 (98.0\%) & 49 (98.0\%) & $143(95.3 \%)$ & \\
\hline \multicolumn{6}{|c|}{ Phlebitis grade } \\
\hline 1 & $3(60.0 \%)$ & Z & $1(100.0 \%)$ & $4(57.1 \%)$ & \multirow[t]{2}{*}{ NA } \\
\hline 2 & $2(40.0 \%)$ & $1(100.0 \%)$ & Z & $3(42.9 \%)$ & \\
\hline \multicolumn{6}{|l|}{ Infiltration } \\
\hline Yes & $25(50.0 \%)$ & $19(38.0 \%)$ & $39(78.0 \%)$ & $83(55.3 \%)$ & \multirow[t]{2}{*}{$p<0.001$} \\
\hline No & $25(50.0 \%)$ & $31(62.0 \%)$ & $11(22.0 \%)$ & $67(44.7 \%)$ & \\
\hline \multicolumn{6}{|c|}{ Infiltration grade } \\
\hline 1 & $20(80.0 \%)$ & $14(73.7 \%)$ & $33(84.6 \%)$ & $67(80.7 \%)$ & \multirow{3}{*}{$p=0.613$} \\
\hline 2 & $5(20.0 \%)$ & $5(26.3 \%)$ & $5(12.8 \%)$ & $15(18.1 \%)$ & \\
\hline 3 & Z & Z & $1(2.6 \%)$ & $1(1.2 \%)$ & \\
\hline $\begin{array}{l}\text { Blood Flow } \\
\text { Block }\end{array}$ & $5(13.2 \%)$ & $5(16.7 \%)$ & $3(6.7 \%)$ & $13(11.5 \%)$ & NA \\
\hline $\begin{array}{l}\text { Accidental } \\
\text { Removal }\end{array}$ & $2(5.2 \%)$ & $3(10.0 \%)$ & $1(2.2 \%)$ & $6(5.3 \%)$ & NA \\
\hline Kinking & $\mathrm{z}$ & $1(3.3 \%)$ & $1(2.2 \%)$ & $2(1.8 \%)$ & NA \\
\hline $\begin{array}{l}\text { Others } \\
\text { Occurrences }\end{array}$ & $1(2.6 \%)$ & $1(3.3 \%)$ & Z & $2(1.8 \%)$ & NA \\
\hline
\end{tabular}

According to related findings (Table 1 ), predominant reasons for catheter removal were adverse events, with statistically significant difference between the three groups $(p=0.015)$.

Phlebitis occurrences $(7 ; 4.7 \%)$ were not shown to be statistically difference between the three groups $(p=0.091)$, related to 150 peripheral venous catheters.

Severe infiltration occurrences were mostly seen in the Grade 1 ratings ( $80.7 \%$ ), followed by Grade $2(18.1 \%)$ and Grade $3(1.2 \%)$; no statistical distribution significance was observed amongst the three studied groups $(p=0.613)$. Severe phlebitis occurrences were also investigated where Grade 1 comprised $57.1 \%$ of the cases and Grade 2 comprised $49.9 \%$. In view of the low frequency levels of phlebitis occurrences in each of the studied groups, no statistical test was carried out on these findings.

Considering research power of 0.800 , the sample provides significant results on the effect of 
dressing on infiltration occurrence (0.967) and further researches on the subjects must be developed to analyze the influence of dressing on phlebitis (0.486) and infiltration grade $(0.220)$, in patients with similar demographic characteristics.

In relation to the maintenance methods, the majority were continuously maintained $(90.7 \%)$ in the three studied groups $(p=0.359)$. With regard to the total parenteral nutrition infusion, 142 (94.7\%) of the studied catheters did not receive this type of infusion, where groups showed no relevant difference among them $(p=0.180)$. From the total of 150 studied catheters, 105 (70.0\%) were infused with some type of antibiotic agent and no evidence was observed of a statistically significant difference $(p=0.076)$ among the groups. In $52.4 \%$ of the studied cases, only one type of antibiotic was administered while in $47.6 \%$, two to four types of antibiotics were infused through the catheter, and homogeneity was observed between the three groups $(p=0.485)$.

No statistically significant difference $(p=$ 0.980 ) was identified among the catheter - inserted blood vessels in the three studied groups, these being mainly in upper limbs blood vessels such as the dorsal venous arch of the hand $(31.3 \%)$, cephalic $(24.0 \%)$ and basilic (12.7\%). Lower limb vessels were not the preferred catheter insertion site $(16.6 \%)$, however, the vena saphena magna $(7.3 \%)$, the dorsal venous arch of the foot $(6.0 \%)$ and the popliteal vein $(3.3 \%)$ were used when necessary. The surrounding region of the catheter site was not statistically different amongst the studied groups $(p=0.960)$. The prevailing insertion sites were the superficial veins of the forearm $(51.3 \%)$ and hands (31.3\%).

\section{DISCUSSION}

Regarding the children's descriptive variables, investigations were focused on their age, sex, skin color, nutritional status, and surgically-treated vital system. Group homogeneity was evidenced by the predominantly male children's preschool age, brown skin, with eutrophic conditions, and by the undergoing of treatment for surgical gastrointestinal disease. The Nursing technicians' professional category showed a statistically prevailing number of venous punctures $(p=0.029)$ when compared to other peripheral venous puncture performers; no statistical difference was observed concerning the group dressing performers studied $(p=0.184)$. In Brazil, registered nurses and nurses' technicians have similar attributions with regard to the performance of peripheral intravenous punctures.

Peripheral intravenous therapy may be considered one of the most common procedures carried out in hospitalized children. Catheter quality, effectiveness, and dressing type are of major importance for satisfactory performance ${ }^{(4,8)}$.

Adverse events included infiltration, obstruction, phlebitis, accidental removal and kinking. Phlebitis was identified in our study as being within an acceptable occurrence range $(4.7 \%)$, as stated by the Infusion Nursing Society ${ }^{(10)}$ when analyzed among 150 peripheral venous catheters. The use of Teflon ${ }^{\circledR}$ catheters is also linked to low phlebitis rates, when compared with polyvinylchloride, polyethylene or needle catheters ${ }^{(13)}$.

Akin to authors, who have studied dressings extensively, and their influence on phlebitis occurrences, our study, in which the study group received adhesive tape over the insertion site, showed levels of phlebitis to be five-fold greater than that of other dressing regimens ${ }^{(9,14)}$.

According to the Phlebitis Rating Scale, our identified cases of phlebitis could be assigned to Grade 1 and 2. Despite extensive related literature, further studies on the subject are still being carried out ${ }^{(5)}$.

Infiltration, related to the dressing regimen, was the most frequent occurrence observed in our study; our findings showed the sterilized transparent film as being the major factor in infiltration occurrences. Our investigation presented similar findings compared to other studies ${ }^{(7,15)}$. Significant differences could be observed between the use of different dressing regimens; however, as previously stated, the sterilized transparent film dressing was a major infiltration factor that can be related to the performance of this dressing, that should be manufactured in accordance to the needs of tropical climate areas' population.

The dressings influenced the dependent variables, $113(75.3 \%)$ catheters were removed because of adverse events, and $37(24.7 \%)$ due to patients' hospital discharge.

In relation to peripheral venous catheter variables, it was observed that 24G was the preferred caliber for intravenous puncture and also was the most suitable for the children's age range studied while smaller diameter catheters were generally used for the venous dorsal arch of the hand, cephalic veins, and upper limb basilic vein $(82.7 \%)$ infusions. The use of smaller-caliber catheters is related to reducing the occurrence of phlebitis, since they 
prevent mechanical irritation to the inside of smalldiameter veins ${ }^{(4,16)}$.

Limb immobilization was observed in the majority of the sample, where the use of a splint was implemented to reduce the mobility of the catheterized limb, thereby reducing the occurrence of accidental catheter withdrawal from inside the vein and avoiding infiltration. However, even with the predominance of immobilization, a frequency of $55.3 \%$ was observed for this type of complication.

From $136(90.7 \%)$ continuously maintained catheters, $14(9.3 \%)$ were intermittently maintained according to the children's nutritional or clinical needs. Some type of antibiotic agent was infused in the majority of the catheters studied. Our subjects, prone to chemical phlebitis occurrences, and infiltrations, also received a larger amount of antibiotics compared to studies ${ }^{(5)}$. This fact may be ascribed to some antibiotics' low pH levels, which

\section{REFERENCES}

1. Hoffman KK, Weber DJ, Samsa GP, Rutala WA. Transparent polyurethane film as an intravenous catheter dressing: a metaanalysis of the infection risks. JAMA 1992; 267: 2072-6.

2. Pettit DM, Kraus V. The use of gauze versus transparent dressings for peripheral intravenous catheter sites. Nurs Clin North Am 1995; 30(3):495-506.

3. Redelmeier DA, Livesley NJ. Adhesive tape and intravascular - catheter - associated infections. J Gen Intern Med 1999; 14(6):373-5.

4. Phillips LD. Complicações da terapia intravenosa. In: Phillips LD. Manual de Terapia Intravenosa. $2^{\mathrm{a}}$ ed. Porto Alegre: Artmed; 2001. p. 236-68.

5. Foster L, Wallis M, Paterson B, James H. A descriptive study of peripheral intravenous catheters in patients admitted to a pediatric unit in one australian hospital. J Infus Nurs 2002; 25(3):159-67.

6. Centers for Disease Control and Prevention. Guidelines for the prevention of intravascular catheter-related infections. MMWR 2002; 51(RR-10).

7. Callaghan S, Copnell B, Johnston L. Comparison of two methods of peripheral intravenous cannula securement in the pediatric setting. J Infus Nurs 2002; 25(4):256-64. are likely to increase the incidence of these complications.

\section{CONCLUSION}

Dressing regimens influenced the reasons for peripheral venous catheter removal, mainly due to infiltration. The Sterile gauze showed the best performance in comparison with the other studied groups.

No influence of the dressing regime was ascribed to phlebitis occurrences. In view of this investigation's findings, and the lack of data on the unique characteristics presented by the population of children living in a warm and humid tropical climate country, it would be important to implement further studies on the significance of intravenous therapy complications related to use of dressings and peripheral venous catheters in such population.

8. Wheeler S, Stoltz S, Maki DG. A prospective, randomized, three-way clinical comparison of a novel, highly permeable, polyurethane dressing with 206 Swan - Ganz pulmonary artery catheters: OpSite IV 3000 vs Tegaderm vs gauze and tape. II Nursing issues: effectiveness and tolerance as catheter dressings. In: Maki DG. Improving catheter site care. London: Royal Society of Medicine Services; 1991. p. 66-9 (International Congress and Symposium Series no. 179). 9. Tripepi-Bova KA, Woods KD, Loach MC. A comparison of transparent polyurethane and dry gauze dressings for peripheral IV catheter sites: rates of phlebitis, infiltration, and dislodgment by patients. Am J Crit Care 1997; 6(5):37781.

10. Machado AF, Pedreira MLG, Chaud MN. Prospective, randomized and controlled trial on the dwell time of peripheral intravenous catheters in children, according to three dressing regimens. Rev Latino-am Enferm, May-June 2005; 13(3): 291-8.

11. Alexander M. Infusion Nursing: Standards of PracticeInfusion-related complications. J Intraven Nurs 2000; 23(6S): S56-S8.

12. Oishi LA. The necessity of routinely replacing peripheral intravenous catheters in hospitalized children. J Intraven Nurs 2001; 24(3): 174-9.

13. Pearson ML. Recommendations for the prevention of nosocomial intravascular related infections. In: Hospita Infection Control Practices Advisory Committee. Atlanta: Center for Disease Control and Prevention; 1995. p. 7-36. 14. Shimandle RB, Johnson D, Baker M, Stotland N, Karrison T, Arnow P. Safety of peripheral intravenous catheters in children. Infect Control Hosp Epidemiol 1999; 20(11):73640 .

15. Almonte R, Patole S, Muller R, Whitehall J. Comparison of two methods of taping peripheral intravenous cannulas. Indian Pediatr 1999; 36(5): 494 -8.

16. Maki DG, Ringer M. Risk factors for infusion-related phlebitis with small peripheral venous catheters: a randomized controlled trial. Ann Intern Med 1991; 114: 845-54. 